\title{
Community Economic Empowerment in Alalak Island Village, Barito District, Barito Kuala, 2017
}

\author{
Nur Jenah", Hairudinnor, Andi Tenry Sompa
}

Master Program of Government Science, Lambung Mangkurat University, Banjarmasin, Indonesia

DOI: $10.36348 /$ sjef.2020.v04i06.004 | Received: 30.05 .2020 | Accepted: 07.06.2020 | Published: 12.06 .2020

*Corresponding author: Nur Jenah

\section{Abstract}

One main goal of village development is to develop development or at least reduce poverty, improve a more decent standard of living. Village development must involve the majority of the population, the results of which can be enjoyed by the entire community. This research uses a qualitative research approach with a phenomenological research type. This is intended to find out and describe in detail and depth about the role of the village government in community economic empowerment in Alalak Island Village, Barito Kuala Regency. The data analysis technique used is an interactive model analysis consisting of data reduction, data presentation, and concluding. The results showed that community economic empowerment in Alalak Island Village Barito Kuala District was intervened by the local government. This is in line with the policy of two programs, namely the empowerment program for micro, small and medium enterprises (MSMEs). Empowerment of the capital sector in the village government is not involved in ever providing financial assistance in the form of empowerment in the capital sector. Factors that support the role of the government in increasing community economic empowerment in Alalak Island Village, Barito Kuala Regency, include the response of community members to village government policy programs. The awareness to participate in community economic empowerment, community members try to dig up information about the possibility of contributing to the implementation of community economic empowerment programs, community culture that can accept changes and developments in aspects of social life.

Keywords: Village development, economic empowerment, and village government.

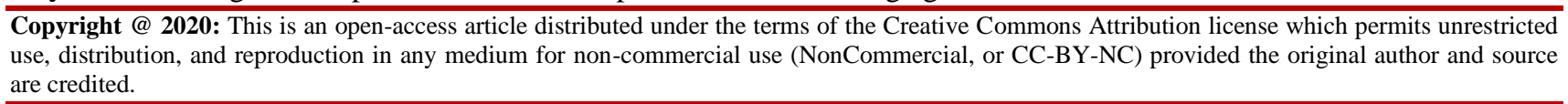

\section{Preliminary}

The birth of Law 23 of 2014 concerning Regional Government and Law No. 6 of 2014 concerning Villages provide an opportunity for villagers to manage and manage their households. However, the mandated requirements are needed, that is, carried out with due regard to democratic principles. The community has a fairly central role in determining policy choices that suit their needs and aspirations so that the village head connects the community's tongue to reach the desired development. One of the main goals of village development is to develop development ideally to reduce poverty, improve living standards [1]. Village development must involve a large portion of the population, the results of which can be enjoyed by the entire community [2].

Rural area development is inseparable from the participation of all rural communities [3, 4]. The Village Head's performance carries out the leader's main duties and coordinates the village government in carrying out some of the village's household affairs.
Pulau Alalak Village is the last village of three islands in Barito Kuala Regency. The island, among others; Sugara Island, Sewangi Island, and Alalak Island, Alalak District. Because it is in the middle of the island people are required to cross using a medium boat (ferry). In Alalak Island Village the role of the village government is only for rastra (prosperous rice) so that it is consumptive. Ideally, creative policies should be made so that the community is more productive; technological applications via the internet.

The role of the Alalak Island Village government which was held was expertise training in the field of the special workshop for bandsaw machine tools (wood business), namely in 2016. The training was felt by the community to be very useful because bandsaw entrepreneurs had difficulty repairing broken machines while operating. Therefore, the businessman only takes the machine to the machine repair site which is located very far from the village. After holding the expertise training in the field of bandsaw machine repair, they no longer experience problems if there is 
damage to the machine. The role of the village government in providing skills training was only one time, namely in 2016. The following years were no longer carried out by the village government. This is unfortunate for the villagers,

1. Number of family heads

2. Number of poor families

3. Total population

4. Total population at productive age

5. Number of unemployed residents

Based on the description it can be seen that in Alalak Island Village still has a relatively high number of poor families $(29.07 \%)$, where the number of people who do not have permanent jobs is 1051 people $(33.74 \%)$. This has become a serious social problem, bearing in mind that each year the population of the village is always increasing, wherein 2016 the population increased to 3,776 with a productive population of 2,558 (67.74\%), and an unemployment rate of 1,218 souls $(32.26 \%)$. Whereas in 2017 the number of occupations was 4,168 people with a productive population of 2,736 people $(65.64 \%)$, and an unemployment rate of 1,432 people $(34.36 \%)$ [5].

The role of the village government is needed to be able to increase community economic empowerment. The 2017 Village Budget (APBDes) for Alalak Island Village is Rp. 1,119,306,300, consisting of Rp. 335,613,500 for Village Fund Allocation (ADD), Rp. 778,191,300 for the Village Fund, and Rp. 5,501,500 for tax and retribution sharing. Government programs for the economic empowerment of the poor that are currently being activated are rastra (prosperous rice), PKH (Family Hope Program), JKN (National Health Insurance), and KIP (Kartu Indonesia Pintar). This article aims to describe how vital the role of the village government is to provide increased community economic empowerment on Alalak Barito Kuala Island.

\section{RESEARCH METHODS}

The research uses a qualitative research approach. The qualitative approach is intended to illustrate the role of the village government in community economic empowerment in Alalak Island Village, Barito Kuala Regency in 2017. A qualitative approach that is not rigid is expected to be able to present a clear picture of issues related to research so that data and information provided to the public are more accurate and can change the performance of village governments [6]. For this reason, the study in this study is analyzing the role of village governments in the economic empowerment of rural communities. The type of research used is descriptive research.

The research location was in the Alalak Island Village Office, Barito Kuala Regency, and South Kalimantan Province. The main instrument in this study
Based on information obtained from one of the village officials, the number of poor people in 2015 was 148 households. Their livelihood is mostly bandsaw. The social disparity of the community which is currently still a problem in the Village of Alalak Island can be seen in the following description.

$=853$ heads of family

$=148(29.07 \%)$

$=3115$ people

$=2064(66.26 \%)$

$=1051(33.74 \%)$

is the researcher himself and the supporting instrument consists of writing instruments for recording in the form of books and other stationery to record the results of the interview, a photo camera to document both the activity and the physics associated with the research. Data collection techniques are used in three steps; Observation; collecting data directly in the field, the object of observation is the Village Office on Alalak Island, Barito Kuala Regency, Interview; explore indepth information about matters relating to research with informants or informants, Documentation;

The focus of the research relates to the role of the village government in community economic empowerment, namely the administration of government affairs and the interests of local communities in the Indonesian government system. The data analysis technique used is an interactive model of analysis as stated by Miles and Huberman [7] that the analysis consists of three stages:

1. Data Reduction is the data obtained at the research location (field data) outlined in a detailed and detailed description or report. The field report will be reduced, summarized, and subject matter focused on the important matters then the theme or pattern is sought.

2. Presentation of Data is to make it easier for researchers to see the overall picture or certain parts of the study.

3. The conclusion is to verify from the beginning entering the research location and during the process of data collection, the author tries to analyze and look for the meaning of the data collected by looking for themes, patterns, and equality relationships, things that often arise, hypotheses and so forth as outlined in conclusions [8].

\section{RESEARCH RESULTS AND DISCUSSION \\ The Role of Village Governments in Increasing Community Economic Empowerment}

Community empowerment arises because of the low socio-economic conditions of the community resulting in them being unable and ignorant. The inability and ignorance of the people resulted in their low productivity. Community empowerment in Alalak Island Village is carried out through community 
development and community organizing. The development of community potential is the potential or ability and attitude to life. The ability of the community can include, among others, the ability to farm, raise livestock, do entrepreneurship, or other skills, and many more abilities and skills of the community that can be developed.

Capacity building and community skills can be done in various ways. For example, in the process of empowerment which is carried out by holding training or involving the community, especially training in the development of abilities and skills. In this study, the development and economic empowerment of the community carried out by the government of Alalak Island Village Barito Kuala Regency are divided into two sectors, namely the micro, small and medium business sector, and the capital sector.

Poverty reduction is very complex and complicated. Therefore, national and agricultural-based national economic development directly or indirectly has an impact on reducing the poor population and the implementation of social welfare can also run as has been aspired. The fundamental problem in community empowerment, especially entrepreneurs, traders, and laborers, which is faced by farmers, is the lack of access to capital resources, markets and technology, and farmer organizations that are still weak.

The role of the government in community empowerment is a stage to increase independence, yields, and welfare of the community in their lives so that the community can utilize information and results of studies conducted jointly by the community together with the facilitator team, to develop the work plan of the farming community so that it is more advanced and independent. Where the measure of success is physical progress or plant area. Therefore, community participation in the preservation of agricultural land becomes very important, because although there has been a role for the government in community empowerment without community participation, the success rate of agricultural business development is very low and at the same time the community remains poor or even becomes poorer.

The role of the village government is entirely the responsibility of the village head and all village officials. This is following Law No. 6 of 2014 Article 26 of the Village Head in charge of organizing village governance, carrying out village development, village community development, and empowerment of village communities. In carrying out the task of empowering the economy of the village community, the village head has the authority to foster the life of the village community, fostering and improving the village economy and integrating it to achieve a productive scale economy for the greatest prosperity of the village community, developing the socio-cultural life of the village community, and utilizing appropriate technology.

Based on the findings in the field, the researchers summarize two important things in the economic empowerment of rural communities, which include the empowerment of micro, small and medium enterprises (MSMEs), which include human resource development, group institutional development, community capital development, development productive business, and the provision of appropriate information. While the empowerment of the capital sector is a discussion of meeting the needs of venture capital can be done by rural communities in groups.

\section{The Role of Village Governments in Empowering Micro, Small and Medium Enterprises (MSMEs)}

The Village Government of Alalak Island, Barito Kuala Regency, in developing micro, small and medium businesses, involves all village government officials and all components of the community who have the will and potential to implement it. The roles carried out by the village government of Alalak Village in the development of micro, small and medium enterprises are as follows:

\section{Development Resource Human}

Human Resources Development (HRD) or Human Resources Development (HRD) is a deliberate learning process that is carried out for a certain time to develop the knowledge, skills, competencies, attitudes, and behaviors of rural communities that are expected to have an impact on individual and group performance. The development of human resources carried out in Alalak Island Village is one of the empowerment strategies to improve the abilities of various skills and potentials that the community has by maximizing them. Through the development of human resources will certainly greatly affect the development of the village itself, with skilled and good human resources, support for various forms of community activities related to the village will also be better [9].

Human resource development in Alalak Island Village is rarely carried out by the village government. The village government has only once carried out the development of human resources in the form of skills training, in 2016 where the training was conducted only for the field of the workshop for the repair of machines and equipment bandsaw, training in making household goods from wood, and others;. 
Table-1: Data on Workshop on Workshop in Alalak Island Village Barito Kuala Regency

\begin{tabular}{|c|l|l|c|}
\hline \multirow{2}{*}{ Year } & \multicolumn{1}{|c|}{ Type of Training } & \multicolumn{1}{|c|}{ Instructor } & $\begin{array}{c}\text { Number of } \\
\text { participants }\end{array}$ \\
\hline \multirow{2}{*}{2012} & Introduction of lathes and scaffolding machines & Banjarmasin City Job Training Center & 14 people \\
\cline { 2 - 4 } & Processing of household appliances (furniture) & Banjarmasin City Job Training Center & 11 people \\
\hline 2015 & Repair of dynamos and mowers & Banjarmasin City Job Training Center & 17 people \\
\hline 2016 & Repair of mowers and reaper machines & Village Self-Help & 23 people \\
\hline
\end{tabular}

Source: Office of Community Empowerment and Village Government (2018)

Based on these data it can be seen that Alalak Island Village has conducted training in human resources aimed at increasing the ability and expertise of community members in certain fields to support their work. Every training conducted is always in demand by the community, especially those who need knowledge, understanding, and expertise in the workshop area.

The last training was in 2016. This was very unfortunate because it was very much needed by the villagers. Besides going through various human resource development training as one of the community empowerment strategies, it can be seen from how the response and participation of the surrounding community towards village development. The initial establishment of the village certainly involved the entire community to be able to support its development, through socialization to the RW and RT. Community participation in supporting and developing villages.

Community empowerment is an effort to increase the power or strength of the community by providing encouragement, opportunities, opportunities, and protection by not regulating and controlling the activities of the community empowered to develop their potential so that the community can increase their ability and actualize themselves or participate through various activities. Society is a group of people who mutually interacting continuously so that there are patterned, organized social relations. Humans, both as individuals and as citizens have needs in community life [10].

\section{Group Institutional Development}

The strategy of community empowerment in the village can also be done through the development of group institutions. One that is very prominent and plays an important role in village development is the village community working group, which is a group that moves and optimizes all activities related to business development. In Alalak Island Village there is a group that was originally spearheaded by 4 people and has now been added by several members. But this institution existed before the village was formed; the people who joined the group already had ideas and saw the unique potential that existed in Alalak Island Village, which was engaged in the timber business. Routine activities carried out by this working group are to coordinate work and cooperate.

The Department of Community Empowerment has now succeeded in gathering community business group resources, where this institution is also one of the important bridges for the people of Pulau Alalak Village to become a better village over time. The formation of the village government also encouraged the community to form several related groups aimed at supporting these needs. Alalak Island Village has community groups including traders, bandsaw business groups, farmer groups, and employee/employee groups.

Table-2: Data from the Village Community Working Group Alalak Island Barito Kuala Regency

\begin{tabular}{|l|l|c|c|}
\multicolumn{2}{|c|}{ Table-2: Data from the Village Community Working Group Alalak Island Barito Kuala Regency } \\
\hline \multirow{2}{*}{ Type of business } & \multicolumn{1}{|c|}{ Business Field Specifications } & $\begin{array}{c}\text { Number of Working } \\
\text { Groups }\end{array}$ & $\begin{array}{c}\text { Total Working } \\
\text { Group Members }\end{array}$ \\
\hline \multirow{2}{*}{ Trading } & Procurement of agricultural equipment & 2 & 6 \\
\cline { 2 - 4 } & Procurement of workshop equipment & 2 & 11 \\
\hline \multirow{4}{*}{ Domestic industry } & Food processing & 3 & 9 \\
\cline { 2 - 4 } & Processing fishing equipment & 3 & 11 \\
\cline { 2 - 4 } & Sasasangan fabric processing & 2 & 5 \\
\hline \multirow{4}{*}{ Wood Processing } & Cutting wood & 31 & 27 \\
\cline { 2 - 4 } & Sale of wood & 11 & 21 \\
\cline { 2 - 4 } & Door and frame processing & 6 & 10 \\
\cline { 2 - 4 } & Furniture processing & 4 & 12 \\
\hline Agriculture & Rice fieldwork & 2 & 196 \\
\hline \multicolumn{2}{|r|}{} & 66 & \\
\hline
\end{tabular}

Source: Office of Community Empowerment and Village Government (2018)

Based on the table, it appears that the largest community working group is in the wood processing business. This is because in the dominant Pulau Desa are wood processing entrepreneurs such as bandsaw, and making wood materials and equipment. The working group is generally formed solely based on the 
awareness and needs of a group of people who have the same goal, while only a small portion is formed by the village government, such as the procurement of agricultural equipment and the Sasakangan fabric home industry. The community groups were formed due to the development of the village, intended to make it easier to bring up some of the potentials of the existing area more optimally through these groupings. Business groups generally consist of 5 to 10 people who have the same business character and have an adjacent residence. This forms a situation in the form of new business centers to facilitate the delivery of information and the provision of directives for developing the overall business potential of the community [11].

At present, only a part of the working group is left, namely wood processing working groups and procurement of workshop equipment. Other workgroups tend to be seasonal, such as farmer groups that only work during the growing season or harvest season. Alalak Island Village Government should be able to maximize its role in fostering business groups in the village; this can be implemented by using expert staff and competence from village officials in the implementation and implementation of policies in group institutional development.

\section{Community Capital Development}

Community capital development is one of the important strategies that must be carried out to facilitate the development of a village. Through the capital available to rural communities, it is easier for them to be able to continue to develop their businesses and increase the quality and quantity of production to meet the demands that come. Community capital development in Alalak Island Village is still not optimal.

The Village Government of Alalak Island still has minimal village funds so that it has not been able to allocate towards the development of micro small and medium enterprises in the village. Capital obtained by the community to develop the village in the form of money and also in the form of goods needed for the purchase of bandsaw equipment and the furniture industry. Capital development for the community in Alalak Island Village is still very minimal because capital is only obtained when in the early days of village formation. The village does not yet have a village business in the form of BUMDes, so for business development and economic empowerment, the village community is still severely constrained.

Alalak Island Village Government must at least have this community capital development strategy, packaged in a joint forum sheltered by the Kelurahan namely the BUMDES (Village-Owned Enterprises) unit, and from outside parties will also be invited to join. Through BUMDES, it is hoped that it can become a forum for stakeholders, Alalak Island community for business units because BUMDES is a form of local village government strategy to be able to accommodate the community / economic actors to be more maximal as one of the supporters in Alalak Island Village.

\section{Productive Business Development}

Empowerment strategies that can be carried out besides developing human resources are also carried out through developing productive businesses. In this study, an empowerment strategy through the development of productive businesses has been carried out in Alalak Island Village. The development of productive businesses becomes an important activity to support the development of villages so that they are even better. Through the development of productive businesses, it also invites the community to participate optimally by participating in opening various productive businesses, including trade, furniture industry, and the bandsaw industry. Alalak Island Village itself has developed productive businesses aimed at the community to increase household income.

The development of various productive businesses is carried out by community members to always optimize and utilize what has become the potential of the village. All that's left is to develop and manage it better to support the satisfaction of the women. The efforts of the community existed since before the village was formed, so that it is no longer something that has just been made. That is what finally became a regional characteristic and original potential that was not made up.

The development of this productive business has not been carried out optimally by the village government of Alalak Island, even though this is very important for the community. The aim of developing and increasing productive economic endeavors is to encourage increased business activity and creativity in community groups in food-insecure/poor areas while providing capital assistance is intended to increase and develop group businesses in developing community businesses.

Productive business activities in addition to increasing community empowerment, creating jobs and fostering entrepreneurial spirit and spirit, developing activities and business opportunities based on local potential, increasing income, increasing food security, and developing local food stocks (food reserves). The target of productive business development activities is for the community to have micro-businesses in services, trade, industry/crafts, and agriculture. The type of business is chosen based on the results of the identification of local potential which is managed by the community micro-business group.

\section{Provision of Appropriate Information}

The village in its development could not merely be famous without information or some kind of 
publication to outsiders. Through good publications, the village will also be easily known by the people of South Kalimantan in general, Barito Kuala Regency and Banjarmasin City in particular. Provision of information is one of the empowerment strategies for the community in a village, because with so many news and publications that are right on target, finally, it forms community opinion that Desa Alalak Island is a village producing centers for certain products or businesses. This greatly supports business development for the village community directly or indirectly.

The development of science and technology which is marked by advancements in the field of communication and information technology today has been so rapid so that it puts society forward. The national program for community empowerment in the poverty alleviation sector is an example to suggest that a program that consumes large costs cannot be carried out optimally if it is not supported by efforts to utilize targeted and integrated information services, namely by making the best use of available information technology facilities. This has become an interesting discourse because the reality in the life of our society today still shows some unfavorable symptoms.

The information technology that is used for information services to the public allows for the instant exchange of information without being limited by space and time. This certainly supports a scientific discipline or a type of work that requires a speed of access to information such as journalism or economics. Journalism is a type of work that prioritizes actuality/speed; whereas in the economic / business sector the acceleration of information affects profitability or vice versa.

\section{Capital Sector Empowerment}

Based on the results of interviews with the Village Head of Alalak Island it can be seen that the village government was seldom involved in ever providing financial assistance in the form of empowerment in the capital sector. The lack of coordination between the Alalak Island Village Government and the facilitator is also unfortunate, the lack of coordination can be seen in terms of the socialization of the village community economic empowerment program that is being intensively socialized by the Barito Kuala District Government through the facilitator. The reality is that when trying to conduct socialization there is no intense coordination with the village government.

Most of the people in Alalak Island Village do not understand yet understand the fulfillment of capital needs so that the problem of venture capital is a major problem that is very difficult for them to solve. Alalak Island Village does not yet have a UPK, so people tend not to understand the systems and procedures for meeting business capital needs by making capital loans.
Because loans are used as business capital and loans submitted by each member of the community following the ability to pay installments of each member, the installments and costs are considered not burdensome, so people tend to pay installments on time.

Fulfillment of business capital needs can be done by village communities in groups, namely by forming business groups that are approved by the Village Head so that the credit application is made on behalf of the business group based on the approval of the Village Head through the District UPK. Meeting the capital needs with this business group system is only done once a year so that if there is a sudden or urgent need for capital, community members cannot apply for a loan from the banking sector. Capital empowerment for rural communities is aimed at increasing the income of people who have businesses so that the main target in capital empowerment can be achieved such as:

1. Reduction in the number of poor people.

2. The development of income generation businesses conducted by the poor by utilizing available resources.

3. Increased public awareness of efforts to improve family welfare.

4. Increased group independence.

5. Increased community capacity and income distribution marked by an increase in income marked by an increase in the income of poor families.

Supporting Factors of the Government's Role in Increasing Community Economic Empowerment

Based on the description of the efforts and implementation of community economic empowerment in Alalak Island Village, the factors supporting the role of the government of Alalak Island Village in enhancing community economic empowerment include the following:

Community Members' Response to the Village Government's Policy Program in Empowering the Village Community's Economy.

The people of Desa Alalak Village still have enthusiasm and confidence in the seriousness of the village government to carry out community empowerment efforts. This was reviewed based on several proposals from the community towards the village government in the form of village infrastructure development that responded quickly and was realized properly according to the needs of the village community. Based on this, the village community has the confidence that they have the opportunity to obtain economic empowerment in the form of various kinds of assistance as other villages. 


\section{There is awareness to Participate in Community Economic Empowerment}

The participation of the village community in each economic empowerment program is quite good, where all sectors contained in the empowerment program are put to good use by community members. Community members try to be able to dig up information about the possibility of contributing to the implementation of community economic empowerment programs, hoping to receive assistance in the form of training, capital, and information technology for them to improve productivity daily effort.

The role of the community in economic empowerment includes direct and indirect involvement. Direct involvement is participating as a participant in fostering community economic empowerment through workgroups and individuals. Whereas indirect involvement is a role in facilitating or delivering information to people in need.

Community culture that can accept changes and developments in aspects of social life

Socio-cultural changes that occur in society, some people can accept and some who cannot accept. People who cannot accept change usually have a traditional mindset. Changes that occur in society are normal. Its influence spread quickly into people's lives. Even changes that occur somewhere in can influence another place. The changes that occur are increasingly developing as the development of people's lives in this era of modernization and globalization. That change is what influenced people's behavior in life.

The people of Alalak Island Village can accept social change and development, especially economic development. This is because globalization factors affect almost all aspects of people's lives. Some people can accept globalization, such as the younger generation, residents with high social status, and urban communities. However, some people are difficult to accept or even reject globalization such as people in remote areas, older generations whose lives are stagnant, and people who are not ready physically or mentally. The elements of globalization that are difficult for society to accept are as follows.

1. Complicated and expensive technology.

2. External cultural elements that are ideological and religious.

3. Cultural elements that are difficult to adjust to the conditions of society.

A positive attitude shows the form of public acceptance of the flow of modernization and globalization. A positive attitude contains the elements of acceptance openly (open-minded); this attitude is the first step to accept the effects of modernization and globalization. Openness makes us more dynamic, not shackled by old things that are old-fashioned, and easy to accept the changes and progress of the times. Develop anticipatory and selective attitudes; this attitude is a continuation of an open attitude. After we can open ourselves from new things, the next step is we must have sensitivity (anticipative) in assessing things that occur related to the influence of modernization and globalization. Anticipatory attitude can show the influence arising from the current of globalization and modernization.

This attitude is a continuation of the anticipatory and selective attitude. An adaptive attitude is an attitude that can adjust to the results of the development of modernization and globalization. Of course, the adjustment made is selective, meaning that it has a positive influence on the community. Society does not have to abandon the elements of the original culture, often the progress of time changes human behavior, obscures the existing culture, even eliminates it. This condition causes a person/community to lose their identity, this condition must be avoided. Forward any the impact of modernization that we go through, we must not leave the elements of the original culture as self-identity.

Factors Inhibiting the Role of the Government in
Increasing Community Economic Empowerment
The still minimal implementation of community empowerment in Alalak Island Village is inseparable from several factors that hinder the implementation of community empowerment, as follows:

\section{Fill out the policy}

Policy implementation fails because the contents of the policy are still vague, meaning that the objectives are not detailed enough, the means and application of priorities, or policy programs are too general or completely absent. Lack of internal or external statutes of policies implemented. The implemented policy can also show significant shortcomings. Other causes of the failure to implement a public policy can occur due to deficiencies concerning auxiliary resources, for example, those concerning time, cost/funds, and human resources.

The Alalak Island Village Government has not optimized the opportunity to establish Village Owned Enterprises (BUMDes) so that economic empowerment policies are very difficult to implement strategically. The existence of Village-Owned Enterprises (BUMDes) is very beneficial for the economy of rural communities, where the BUMDes can be formed based on the high interests of the community towards certain economic sectors to overcome the real economic problems in the village, both in the form of procurement of goods and business capital. BUMDes as a community business entity institutionally will greatly benefit the economic development potential of the village. 


\section{Limitations of Access with Other Parties}

Limitationaccess and cooperation between the village government and other institutions in the application of community economic empowerment, such as capital from banks. This is because the village government was not facilitated by the authority to submit banking capital, so the process of providing practical assistance through banking tends to be carried out by community members directly to the banks.

The village government still uses village funds and government assistance in providing capital assistance to village communities. This only happens in certain periods which means only when there is program implementation. While the capital needs of businesses that occur in the community cannot be predicted, so many villagers tend to apply for capital loan assistance directly to the banks. Based on this, the Alalak Island Village government needs to optimize the establishment of BUMDes and cooperation with the district and provincial governments for banking access, to facilitate the fulfillment of capital needs for community businesses as a group or individually.

\section{CONCLUSION}

Micro, small and medium enterprise (MSME) empowerment program, in which the Alalak Island Village Government Barito Kuala Regency in conducting development involves all village government officials and all components of the community that have the will and potential. The implementation, such as; human resource development, group institutions, community capital, productive businesses, and the provision of appropriate information. But in the empowerment of the capital sector, the village government is almost not involved. Lack of coordination between the Alalak Island Village Government and the facilitator can be seen in terms of the socialization of the village community economic empowerment program that is being intensively socialized by the Barito Kuala District Government through the facilitator.

The supporting factors of the government's role in increasing community economic empowerment in Desa Alalak Island Barito Kuala Regency in 2017 are as follows: First, the response of community members to the village government's policy program in empowering the economy of the village community. The people of Alalak Island Village have enthusiasm and confidence in the seriousness of the village government to carry out community empowerment efforts. Some proposals from the community towards the village government in the form of village infrastructure development were responded to quickly and were realized properly according to the needs of the village community. Secondly, there is awareness to play a role in community economic empowerment, where every program implemented by the village government is put to good use by community members. Third, community members try to dig up information about the possible contribution of the implementation of community economic empowerment programs. Third, the culture of the society that can accept changes and developments in aspects of social life.

The inhibiting factors of the government's role in increasing community economic empowerment in Alalak Island Village, Barito Kuala Regency in 2017, are as follows: First, some policies are difficult to implement, because most of the policy directions have not been implemented. This is because the tendency of results is not on target, such as; technology development, increasing public knowledge about the business sector. Second, limited access and cooperation between the village government and institutions. This is because the village government was not facilitated by the authority to submit banking capital so that the provision of practical assistance through banking tends to be done by community members directly to the banks.

\section{REFFERENCE}

1. Hogwood, B. W., \& Lewis, A. G. (2008). Policy Analysis for the Real. Inggris: Oxford University Press.

2. Mubyarto. (1993). Dua puluh Tahun Penelitian Pedesaan. Yogyakarta: Penerbit Aditya Media.

3. Ali, M. (2007). Orang Desa Anak Tiri Perubahan. Malang: Anvorroes Pers.

4. Beratha, N. (1982). Desa, Publik, Konsep, Teori dan Aplikasi. Yogyakarta: Pustaka Pelajar.

5. Mursyidin, D. H., Nazari, Y. A., \& Daryono, B. S. (2017). Tidal swamp rice cultivars of South Kalimantan Province, Indonesia: A case study of diversity and local culture. Biodiversitas Journal of Biological Diversity, 18(1).

6. Nasution. (2003). Metode Penelitian Naturalistik Kualitatif. Bandung: Tarsito.

7. Sugiyono, D. (2008). Metode penelitian bisnis. Bandung: Pusat Bahasa Depdiknas.

8. Moleong, L. J. (2004). Metodologi Penelitian Kualitatif. Bandung: Remaja. Rosdakarya.

9. Sedarmayanti. (2004). Good Government (Pemerintahan yang baik). Bandung: CV. Mandar Maju.

10. Haryadi, D. (2018). Peran Kepala Desa dalam Pelaksanaan Pembangunan Desa Pesisir. Tanjungpinang: Universitas Maritim Raja Ali Haji (Program Studi Ilmu Pemerintahan Fakultas Ilmu Sosial Dan Politik ).

11. Hardiansyah. (2011). Kualitas Pelayanan Publik. Yogyakarta : Gaya Media.

12. Satori, D. (2011). Metode Penelitian Kualitatif. Bandung: Alfabeta. 